\title{
IMPLEMENTASI UNDANG-UNDANG PEMILIHAN UMUM NOMOR 7 TAHUN 2017 DALAM PENETAPAN PARTAI POLITIK PESERTA PEMILU DI KOTA BATAM TAHUN 2019
}

\author{
Johan Sabara ${ }^{1}$, Amrullah Rasal ${ }^{2}$ \\ ${ }^{1}$ Program Studi Ilmu Pemerintahan, Fakultas Ilmu Sosial dan Ilmu Politik, Universitas Riau Kepulauan, \\ Indonesia \\ johan357@gmail.com \\ ${ }^{2}$ Program Studi Ilmu Pemerintahan, Fakultas Ilmu Sosial dan Ilmu Politik, Universitas Riau Kepulauan, \\ Indonesia \\ amrullahrasa167@gmail.com
}

\begin{abstract}
Abstrak
Pemiihan Umum tahun 2019 adalah pemilihan umum serentak untuk memilih DPR, Presiden/Wakil Presiden, DPD, DPRD Propinsi dan DPRD Kabupaten Kota. Salah satu tahap dalam Melaksanakan Pemilu tersebut adalah pendaftaran partai politik yang akan mengikuti pemilu melalui verifikasi administrasi dan verifikasi faktual. KPU telah menentukan 16 Partai Politik yang akan mengikuti pemilu tahun 2019. Metode yang digunakan peneliti dalam penelitian ini adalah deskriptif kualitatif dengan menggunakan studi kasus. Penelitian yang akan mencoba menggambarkan kenyataan serta keadaan objek yang diteliti secara faktual dan akurat untuk dianalisis secara mendetail. Implementasi Undang-Undang Nomor 7 tahun 2017 dalam penetapan partai politik peserta pemilu di Kota Batam tahun 2019 meliputi kerjasama lintas organisasi, standar dan sasaran kebijakan, sumber daya, kondisi social ekonomi dan politik masyarakat serta disposisi implementor. Untuk beberapa hal tertentu masih perlu mendapatkan perhatian yang lebih serius terutama dalam pemberian pembinaan secara berkelanjutan agar penanganannya bisa lebih efektif.

Kata Kunci : Implementasi, Pengarustamaan Gender, Kota Batam.
\end{abstract}

\begin{abstract}
Abstact
General Election in 2019 is a simultaneous general election to elect the DPR, President / Vice President, DPD, Provincial DPRD and City Regency DPRD. One of the stages in the implementation of the General Election is the registration of political parties participating in the election through administrative verification and factual verification. General Election Commissions. The KPU has determined 16 Political Parties participating in the elections in 2019. The research method used in this study was descriptive qualitative using a case study. Research that seeks to describe the reality and state of objects that are systematically, factually and accurately examined to be analyzed in depth. Implementation of Law No. 7 of 2017 in the determination of political parties participating in the elections in Batam City in 2019 includes cooperation between organizations, standards and policy targets, resources, socio-economic and political conditions of the community and the disposition of the implementor. For certain things still need to get more serious attention, especially in providing ongoing development so that the handling can be more effective.
\end{abstract}

Key Word : Implementation, Political Parties, General Election. 


\section{PENDAHULUAN}

Pemilihan umum merupakan sarana pelaksanaan pesta demokrasi yang terbuka, dalam negara indonesia yang berdasarkan pada pasal 1 ayat 920 undang- undang dasar 1945. Yang mengatakan bahwa kedaulatan rakyat berada ditangan rakyat dan diselenggarakan menurut peraturan perundang - undangan. Amanat Konstitusi tersebut bertujuan untuk menjamin terpenuhinya ketentuan perkembangan demokrasi yang searah dengan perkembangan kehidupan berbangsa dan bernegara (Sunggono, 2002: 41).

Pemilihan umum secara langsung yang dilaksanakan dari rakyat oleh rakyat dan rakyat merupakan salah satu bentuk manifestasi kedaulatan rakyat yang bertujuan menghasilkan pemerintahan negara yang demokratis, bersih dan berwibawa berdasarkan Pancasila dan Undang-undang Dasar Negara Republik Indonesia Tahun 1945. Pelaksanaan pemilihan umum secara langsung, umum, bebas, rahasia, jujur, dan adil dapat terealisasi bila dilakukan oleh pihak pelaksana pemilu yang mempunyai integritas, profesionalitas, dan akuntabilitas (Gaffar, 2006: 116).

Pemilihan umum di Indonesia adalah cara bagi rakyat umum untuk memberi dukungannya terhadap calon-calon anggota legislatif dan pimpinan puncak Pemerintahan (eksekutif) yakni Presiden dan Wakil Presiden melalui pemilihan umum yang berdasarkan pada asas Luber serta Jurdil. Perubahan sistem politik dari orde baru ke orde reformasi saat ini telah membawa perubahan besar dalam sistem perpolitikan di Indonesia yang semakin terbuka dan transparan. Setelah orde baru tumbang, kini Indonesia telah berjalan ke tahap institusionalisasi demokrasi, perubahan-perubahan penting telah banyak terjadi seperti dari segi pranata, legal dan institusional. Kita melaksanakan pemilu legislatif dan pemilihan presiden secara langsung, suatu kegiatan demokrasi dimana partisipasi rakyat adalah pondasi utamanya dapat diinstitusinalisasi secara berkala dan regular.

Sebagai instrumen demokrasi, pemilihan umum merupakan perwujudan kedaulatan rakyat dalam menrntukan wakilnya untuk duduk dalam bagian struktur pemerintahan. Pemilu adalah media yang menyalurkan demokrasi yang memberikan kesempatan pada warga yang berkompeten untuk dipilih menjadi wakil rakyat, baik itu eksekutif maupun legislatif. Bahkan jika memenuhi syarat tidak tertutup kemungkinan bahwa warga tersebut bisa dipilih sebagai presiden atau wakil presiden. Hal tersebut adalah bentuk dari asas demokrasi yang menjunjung tinggi kebebasan hak - hak individu selaku warga Indonesia. 
Pemilu adalah bentuk kedaulatan rakyat memberikan kesempatan seluas-luasnya kepada seluruh warga Negara Indonesia untuk menyampaikan hak politiknya sesuai dengan pilihan politik masing-masing. Penyaluran hak politik masyarakat berlandaskan dengan azas pemilihan umum yaitu Luber dan Jurdil.

Dalam Undang - Undang Nomor 17 Tahun 2017 pasal 172 sudah disebutkan bahwa syarat partai politik untuk pemilihan umum anggota DPR, Presiden, DPD, DPRD provinsi, dan DPRD kabupaten/kota adalah anggota parpol. Dan telah dijelaskan juga bahwa parpol yang akan megikuti pemilu merupakan partai politik yang telah ditetapkan/lulus verifikasi oleh KPU yang telah disebutkan pada pasal 173 ayat 1 (satu) dan 2 (dua) dan telah memenuhi persyaratan sebagai berikut:

a. Memiliki status badan hukum sesuai dengan UU tentang Parpol.

b. Mempunyai kepengurusan di seluruh provinsi.

c. Mempunyai kepengurusan di $75 \%$ jumlah kabupaten/kota.

d. Mempunyai kepengurusan di 50\% jumlah kecamatan.

e. Mengikutsertakan paling sedikit $30 \%$ (tiga puluh persen) keanggotaan wanita pada kepengurusan parpol tingkat pusat.

f. Mempunyai anggota paling sedikit 1.000 orang dari Penduduk pada kepengurusan parpol yang memiliki kartu tanda anggota.

g. Mempunyai kantor tetap untuk kepengurusan pada setiap tingkatan.

h. Mengajukan atribut dan logistik partai dan tanda gambar partai politik kepada KPU.

i. Melampirkan nomor rekening bank untuk dana Kampanye Pemilu atas nama parpol kepada KPU.

Keterwakilan 30 (tiga puluh) perempuan khususnya bagi partai baru rata-rata bermasalah. Permasalahan lain adalah verifikasi factual. Dari pencocokan data berdasarkan Kartu Tanda Penduduk (KTP) hampir semua partai politik bermasalah. Permasalahn tersebut berhubungan dengan alamat yang ada di KTP tidak sesuai dengan domisili di lapangan, sehingga pihak KPU Kota Batam mengembalikan dokumen untuk diperbaiki sampai dengan waktu yang telah ditentukan.

Dari latar belakang diatas maka peneliti menarik kesimpulan atas permasalahan yang dihadapi KPU Kota Batam dalam melakukan verifikasi administrasi dan verifikasi faktual sebagai syarat untuk didaftarkan menjadi parpol yang akan mengikuti pemilu tahun 2019: 
1. Ketersediaan 30 (tiga puluh) persen wanita dalam kepengurusan partpol yang tidak terpenuhi terutama bagi partai baru.

2. Pencocokan dan penelitian (coklit) berdasarkan Kartu Tanda Penduduk (KTP) hampir semua partai politik bermasalah.

Penelitian ini memiliki tujuan untuk mengetahui bagaimana berjalannya implementasi Undang-Undang Nomor 7 Tahun 2017 dalam penetapan partai politik peserta pemilihan umum di Kota Batam tahun 2019. penelitian ini dapat menjadi sumber informasi dalam melakukan kajian mengenai implementasi Undang-Undang Nomor 7 Tahun 2017 dalam penetapan partai politik peserta pemilihan umum di Kota Batam tahun 2019.

Hasil kajian penelitian dalam skripsi ini dapat dijadikan referensi bagi peneliti yang akan datang yang akan melakukan penelitian yang lebih luas tentang implementasi UndangUndang Pemilihan Umum Nomor 7 tahun 2017 dalam penetapan partai politik peserta pemilu di Kota Batam tahun 2019.

Penelitian ini diharapkan dapat menambah informasi dan pemahaman yang lebih mendalam terutama bagi partai politik dan masyarakat umum tentang kebijakan yang baru disahkan pada tahun 2017 ini.

\section{METODELOGI}

Jenis penelitian yang peneliti gunakan adalah kualitatif. Menurut Bogman dan Taylor (Moleong, 1995: 47) diartikan sebagai syarat penelitian yang mendapatkan data gambaran berupa kata / lisan dari orang-orang yang dapat dicermati. Penelitian ini dilakukan di Kantor Komisi Pemilihan Umum Daerah (KPU) Kota Batam. Teknik pengumpulan data yang digunakan adalah observasi, wawancara dan dokumentasi. Instrumen penelitian yang digunakan dalam penelitian ini adalah peneliti sendiri, pedoman wawancara, alat perekam dan alat tulis. Analisis data dalam penelitian ini menggunakan Model Interaktif menurut Miles dan Hubberman dalam Sugiyono (2011: 224). Analisis model interaktif tersebut, terdiri dari pengumpulan data, reduksi data, penyajian data, dan penarikan kesimpulan. 


\section{PEMBAHASAN}

Standar dan Sasaran Kebijakan

Standar dan Sasaran ini di ibaratkan seperti sebuah pondasi yang memiliki syarat dan fungsi. Apabila standard dan sasaran kebijakan tidak jelas, Kebijakam akan tidak jelas untuk apa fungsinya dan untuk siapa kebijakan itu dibuat sehingga dapat menimbulkan perbedaan pemahaman dan mudah mengundang perselisihan di antara para implementor. Dalam suatu organisasi termasuk KPU Kota Batam diperlukan pemahaman dan keseragaman langkah antara semua pihak agar tidak terjadi ketimpangan dalam organisasi tersebut. untuk langkah awal dalam proses penyelenggaraan pemilu di Kota Batam tahun 2019 adalah melakukan sosialisasi internal organisasi tentang tugas dan fungsi masing anggota. diketahui bahwa langkah awal yang dilakukan oleh Ketua KPU Kota Batam adalah memberikan pemahaman dan penjelasan kepada seluruh anggota KPU Kota Batam dan kepada seluruh aparat pendukung mengenai tugas inti dan fungsi yang wajib dilaksanakan dalam menentukan tujuan-tujuan kebijakan selanjutnya.

Semua kebijakan yang ditetapkan oleh KPU melalui proses pleno antara seluruh anggota KPU Kota Batam dan menjadi keputusan dan kebijakan bersama untuk menyusun langkah-langkah yang harus ditempuh kedepan agar proses dan tahapan penyelenggaraan pemilu bisa berjalan sesuai dengan target dan sasaran yang telah ditetapkan.

Sumberdaya

Implementasi kebijakan harus ada dukungan sumberdaya baik sumberdaya manusia maupun sumberdaya non-manusia. Implementasi kebijakan perlu dukungan sumberdaya baik sumberdaya manusia maupun sumberdaya alam. Keterbatasan Sumber daya yang dimiliki KPU Kota Batam berpengaruh terhadap implementasi Undang-Undang nomor 7 tahun 2017 khususnya dalam tahapan verifikasi partai politik peserta pemilu tahun 2019. Kondisi sarana dan prasarana Sekretariat KPU Kota Batam kurang memadai. Diperparah lagi dengan posisinya yang terkesan terpencil tidak terawat. Kondisi tersebut memberikan kesan yang kurang nyaman kepada pengurus parpol dalam mengikuti proses verifikasi partai politik peserta pemilu tahun 2019.

Verifikasi faktual partai politik peserta pemilu tahun 2019 pada umumnya terkendala pada ketesediaan 30 (tigapuluh) wanita dalam keanggotaan parpol. Kalaupun terpenuhi, itu terkesan dipaksakan terutama bagi partai pendatang baru. Situasi tersebut akan menghambat 
tahapan pelaksanaan pemilu serentak tahun 2019 yang dilaksanakan oleh KPU Kota Batam khususnya dalam melakukan verifikasi pratai politik.

\section{Hubungan Antar Organisasi}

Dalam mengimplementasikan suatu tujuan kita sulit untuk berhasil mencapai tujuan tersebut. Tidak hanya Dalam Kebijakan, maka dari itu Kebijakan juga perlu adanya dukungan dan kerja sama dengan pihak lain. Untuk itu, diperlukan koordinasi dan kerjasama antar instansi bagi keberhasilan suatu kebijakan. Dalam mendukung kebijakan dalam proses verifikasi faktual parpol peserta pemilu tahun 2019, KPU Kota Batam bekerja sama dengan instansi terkait dalam upaya menjelaskan dan menyampaikan kebijakan ke masyarakat dan anggota parpol.

KPU Kota Batam sebagai pihak pelaksana pemilu tahun 2019 melakukan kerjasama dengan Dinas Komunikasi dan Imformatika Kota Batam dalam rangka mensosialisasikan kebiajakan-kebijakan KPU Kota Batam dengan untuk memberikan pemahaman kepada masyarakat khususnya bagi parpol peserta pemilu tahun 2019 terutama kebijakan terhadap verifikasi faktual partai poltik peserta pemilu tahun 2019. Begitu juga untuk menentukan mekanisme dan tata cara serta persyaratan yang harus dipenuhi oleh setiap parpol peserta pemilu dalam mempersiapkan partainya menghadapi verifikasi faktual.

\section{Karakteristik Agen Pelaksana}

Karakterisik agen pelaksana itu mencakup struktur birokrasi, norma-norma, dan polapola hubungan yang terjadi dalam birokrasi, yang seluruhnya akan berpengaruh pada implementasi suatu kebijakan. Pengalaman-pengalaman subyektivitas individu memegang peranan yang penting. dalam mengimplementasikan Undang-Undang nomor 7 tahun 2017 tentang pelaksanaan pemilu DPR, Presiden dan Wakil Presiden, DPD, DPRD Propinsi dan DPRD Kabupaten Kota khususnya dalam tahapan verifikasi faktual partai politik peserta pemilu tahun 2019. Ada tiga unsur yang terdapat pada agen pelaksana yang mempengaruhi kemampuan dan keinginan mereka untuk melaksanakan kebijakan, yakni: kognisi (komprehensi pemahaman) tentang kebijakan, tanggapan terhadap kebijakan (penerimaan, netralitas, penolakan) dan intensitas tanggapan.

Pelaksana kebijakan pada KPU Kota Batam dapat bekerja dengan optimal bila didukung oleh perilaku-perilaku yang profesional dengan tersedianya tiga unsur di atas, 
di mana tidak jarang implementasi kebijakan mengalami kegagalan karena ketidaktaatan para pelaksana. Karena apabila pelaksana dalam kondisi tidak sesuai dengan kognisinya, maka individu akan berusaha menolak tujuan kebijakan.

\section{Kondisi Sosial, Politik, dan Ekonomi}

Sumber daya ekonomi lingkungan sangat mendukung untuk berhasilnya implementasi kebijakan. Karena kita harus melihat sejauh mana kelompok yang berkepentingan memberi dukungan dalam suatu program kebijakan ini. Dilihat dari tanggapan masyarakat terhadap kebijakan dilingkungan itu, serta apakah elit politik dan implementor juga memberi tanggapan pada kebijakan tersebut.

Kondisi Sosial, ekonomi dan politik mencakup sumberdaya ekonomi yang dapat mendukung berhasilnya implementasi suatu kebijakan, karakterisitik para partisipan, pendapat publik yang ada di lingkungan, dan elit politik mendukung implementasi kebijakan. Perlu dipahami bahwa pelaksanaan Pemilu memang membutuhkan biaya yang cukup besar karena sudah menjadi konsekuensi logis dari sebuah sistem demokrasi langsung yang diselenggarakan. Apalagi dalam praktik demokrasi elektoral, selain mempertimbangkan nilai demokrasi itu sendiri, juga harus mempertimbangkan proses yang dijalankan. Tidak mungkin hanya melihat demokrasi yang dilaksanakan dengan hanya mengedepankan nilai efektif dan efisien semata.

Kondisi sosial ekonomi sangat berpengaruh dalam mengimplementasikan kebijakan yang dikeluarkan oleh KPU Kota Batam terutama dalam proses verifikasi parpol peserta pemilu tahun 2019 karena berhubungan dengan kondisi sosial ekonomi para anggota pengurus. Kondisi tersebut membuat parpol peserta pemilu menghadapi berbagai permasalahan. Kemampuan pengurus partai secara finansial harus dimiliki walaupun tidak disyaratkan secara tertulis tetapi akan menjadi beban moral bagi pengurus khususnya ketua PAC. Pada hal dari sisi SDM ketua PAC tersebut tidak diragukan lagi tapi dari sisi kemampuan secara finansial kadang tidak memenuhi atau tidak sanggup.

\section{Disposisi Implementor}

Disposisi implementor adalah bagaimana tenggapan implementor pada kebijakan tersebut. Apakah ingin melaksanakan kebijakan tersebut atau tidak. Dan juga apakah implementor itu mengerti terhadap kebijakan tersebut atau tidak, dan intensitas disposisi 
implementor adalah preferensi nilai yang dimiliki oleh implementor. Partai politik sebagai implementor atau pelaksana kebijakan yang berhubungan proses penyelenggaraan pemilihan umum diharapkan bisa menumbuhkan komitmen dalam proses penyelenggaraan pemilu dengan menegakkan azas Luber dan Jurdil sebagai Bentuk kedaulatan rakyat. Kenyataan yang ada dilapangan kadang-kadang proses politik diwarnai dengan politik uang atau ada oknum-oknum tertentu yang menggunakan segala macam cara untuk mendapatkan susra atau dukungan dari masyarakat. Ini sangat bertentangan dengan prinsip penyelenggaraan pemilu.

KPU dan partai politik selaku implementor dalam pelaksanaan kebijakan ini diharapkan memiliki sikap baik dalam menjalankan kebijakan ini sesuai peraturan dan undang - undang yang berlaku. Dan sebagai pihak pelaksana pemilu KPU Kota Batam bertindak tegas terhadap segala bentuk pelanggaran pemilu yang dilaksanakan oleh parpol peserta pemilu.

\section{KESIMPULAN}

Dari uraian hasil pembahasan yang telah dikemukakan oleh peneliti tentang implementasi Undang-Undang Nomor 7 Tahun 2017 terhadap penetapan parpol peserta pemilu tahun 2019 dapat ditarik kesimpulan berdasarkan teori yang dijelaskan dalam kerangka pemikiran bahwa implementasi Undang-Undang Nomor 7 tahun 2017 dalam penetapan partai politik peserta pemilu oleh KPU Kota Batam sudah dilaksanakan secara maksimal.

1. Hubungan kerjasama lintas organisasi, KPU Kota Batam telah bekerja sama dengan seluruh instansi atau lembaga terkait dalam rangka mensosialisasikan kebiajakankebijakan untuk memberikan pengertian kepada rakyat umum khususnya yang menyangkut dengan verifikasi faktual parpol peserta pemilu.

2. Implementasi Standar dan Sasaran Kebijakan, KPU Kota Batam telah memberikan penjelasan mengenai tugas dan fungsi kepada pelaksana kebijakan tentang standar atau target yang harus direalisasikan menjelaskanan standar dan tujuan kebijakan diharapkan para pelaksana kebijakan.

3. Sumberdaya baik sumberdaya manusia (human resources) maupun sumberdaya alam yang dimiliki khususnya sarana dan prasarana KPU Kota Batam masih belum maksimal. Keberadaan sekretariat yang jauh dari pusat kota memberikan kesan tidak nyaman bagi partai politik dalam melakukan verifikasi faktual. 
4. Salah satu kendala yang dihadapi dalam melakukan verifikasi faktual parpol peserta pemilu tahun 2019 adalah kesan dari pihak pengurus partai politik yang tidak terlalu siap untuk melalui verifikasi partai politik peserta pemilu khususnya partai pendatang baru.

5. Masalah ekonomi dan sosial berpengaruh dalam melakukan verifikasi penetapan parpol peserta pemilu khususnya bagi parpol pendatang baru dan parpol yang baru dinyatakan lolos menjadi peserta pemilu setelah memenangkan gugatan di MK yaitu PBB dan PKPI. Berbeda dengan partai politik yang sudah mapan dari aspek finansial, itu tidak terlalu menjadi masalah.

6. KPU Kota Batam sebagai implementor tidak akan mentolerir terhadap parpol peserta pemilu yang mencoba melakukan kecurangan terhadap aturan yang yang telah ditentukan secara jelas khususnya dalam proses verifikasi parpol peserta pemilu dengan memberikan janji atau iming-iming agar partainya dipermudah dalam proses verifikasi parpol peserta pemilu.

\section{SARAN}

1. Dalam rangka mengoptimalkan implementasi Undang-Undang Nomor 7 Tahun 2017 tentang Penyelenggaraan Pemilihan Umum DPR, Presiden dan Wakil Presiden, DPD, DPR Propinsi dan DPRD Kabupaten/Kota khususnya dalam tahapan verifikasi faktual partai politik peserta pemilu maka disarankan agar lebih meningkatkan kerjasama antara semua pihak agar terwujud pemiliham umum yang demokratis dan berintegritas beraasaskan langsung, umum, bebas, rahasia, jujur dan adil.

2. Kepada partai politik peserta pemilu untuk lebih membenahi manajemen partai khususnya bagi partai-partai yang baru agar bisa menjadi partai yang menjadi harapan masyarakat untuk menyalurkan aspirasi politik.

3. Kepada para tim penyelenggara pemilu khususnya Badan Pengawas Pemilihan Umum (Bawaslu) agar melakukan pengawasan yang bertanggung jawab dan sebaiknya terjun langsung ke lapangan untuk memantau dan meminimalisir kecurangan-kecurangan yang terjadi dalam penyelenggaraan pemilihan umum. 


\section{DAFTAR PUSTAKA}

Sunggono, Bambang. (2002). Partai Politik dalam Kerangka Pembangunan Politik di Indonesia. Surabaya: PT Bina Ilmu.

Sugiyono. 2011. Metode Penelitian Kuantitatif Kualitatif dan R \&D. Bandung: Alfabeta.

Moleong, L.J. 2007. Metodologi Penelitian Kualitatif. Bandung: PT. Remaja Rosdakarya.

Gaffar, Affan. (2006). Politik Indonesia Transisi Menuju Dmokrasi. Yogyakarta: Pustaka Pelajar. 